\title{
PARADIGMA ETIS DAN METODOLOGIS BAGI DAKWAH STRATEGIS
}

\author{
Shofyan Affandy \\ STID Al-Hadid, Surabaya \\ shofyanaffandy@outlook.co.id
}

\begin{abstract}
Abstrak: Dalam lingkungan dakwah yang semakin dinamis dan kompleks, organisasi dakwah dituntut harus mampu menerapkan manajemen profesional, dan bertransformasi menjadi organisasi pembelajar yang adaptif terhadap dinamika lingkungan dakwah. Agar program dakwah dapat bersifat lebih strategis, lentur, dan mampu bertahan dalam jangka panjang. Untuk itu, perlu dikaji sebuah paradigma berpikir yang mampu memberikan landasan etis dan metodologis bagi pengembangan dakwah strategis. Sehingga dapat menghadirkan sebuah ancangan teoritis bagi kerangka kerja manajemen strategis yang mampu diadaptasikan bagi kepentingan organisasi dakwah. Tulisan ini berbasis pada qualitative nonempirical research (conceptual research) dengan menerapkan analisis sintesis teoritis yang bertujuan untuk mengadaptasikan teori manajemen strategi pada konsep dakwah atau organisasi dakwah. Paradigma etis-normatif bagi dakwah strategis dapat merujuk pada konsep manajemen strategis syariah yang lahir dari semangat Islamisasi ilmu pengetahuan. Paradigma etis ini lebih menekankan pada pengembangan etos kerja SDM dakwah berbasis pada nilai-nilai syariat, tetapi kurang menekankan pada aspek teknis metodologis dalam kerangka kerja manajemen strategis. Sehingga kerangka manajemen strategis syariah ini tidak memiliki perbedaan yang esensial dengan manajemen strategis konvensional. Karena itu diperlukan terobosan analitis untuk merumuskan paradigma metodologis dalam kerangka kerja manajemen strategis agar adaptif bagi dakwah strategis. Paradigma metodologis ini bekerja pada setiap tahapan manajemen strategis, mulai perumusan visi-misi, analisis dan pemilihan strategi, hingga pedoman implementasinya.
\end{abstract}

Kata kunci: manajemen strategi, organisasi dakwah, dakwah strategis, paradigma etis dan metodologis

\begin{abstract}
In a more and more dinamic and complex environment of da'wah, a da'wah organization is demanded to be able to apply professional management, and transforms it into an adaptive learning organization towards the dynamic of da'wah environment. It is intended for making the programs of $d^{\prime}$ 'wah more strategical, flexible, and endurable on a long term. Therefore, it is necessary to consider a thinking paradigm which can provide ethical and methodological paradigm for the development of strategic da'wah. It is intended to present a theoritical plan for the work frame of strategic management which can be adapted for the importance of da'wah organization. This paper is based on qualitative nonempirical research (conceptual research) by applying theoritical synthetic analysis aiming to adapt strategic management theory to da'wah concept or organization. Ethical-normative paradigm for strtageic da'wah can refer to shariah strategic management which was born from the spirit of islamization of science. This ethical paradigm emphasizes more on work ethic development of da'wah human resource based on shariah values, but it is lack of emphasizing oon technical methodological aspect under the frame work of strategic management. Therefore, the shariah strategic management does not have any essential differences with conventional strategic management. Therefore, it is necessary to formulate methodological paradigm in the frame work of strategic management in order to be adaptive for strategic da'wah. This strategic
\end{abstract}


paradigm works in every phase of strategic management, starting from vision and mission formulation, analysis and selection of strategy, until its implementation guidance.

Keywords: strategic management, da'wah organization, strategic da'wah, ethical and methodological paradigm

\section{Pendahuluan}

Organisasi dakwah modern harus berhadapan dengan lingkungan dakwah yang semakin dinamis dan kompleks. Karena itu, organisasi dakwah dituntut harus mampu menerapkan kaidah pengelolaan organisasi berbasis manajemen strategis untuk menjalankan dakwah strategis. Artinya, organisasi dakwah tidak hanya mampu menjalankan proses manajerial dari perencanaan, pengorganisasian, penggerakan, dan pengendalian secara sistematis dan terukur, melainkan juga harus bertransformasi menjadi organisasi pembelajar yang sangat adaptif terhadap dinamika lingkungan dakwah yang dihadapinya. Karena hanya demikianlah, organisasi dakwah akan menjadi lebih berdaya guna secara maksimal dan berjalan secara berkelanjutan dalam jangka waktu yang sangat panjang. Untuk itu, perlu pengkajian teoritis yang sistematis untuk mengembangkan paradigma etis dan metodologis yang dapat melandasi kerangka kerja manajemen strategis untuk diterapkan pada organisasi dakwah.

Berbagai teori manajemen strategi konvensional yang saat ini berkembang berangkat dari kebutuhan organisasi perusahaan yang berorientasi komersial. Kelemahan teori-teori manajemen konvensional adalah bersifat parsial, kurang memperhatikan unsur kemanusiaan pada diri individu, dan lebih berorientasi pada upaya untuk meningkatkan produktivitas dan kompetensi. Teori ini kurang menghargai pengaruh serikat buruh yang membentuk interaksi sosial dan kinerja mereka, serta faktor-faktor lingkungan eksternal lain yang berpengaruh. Landasan ontologis dari teori manajemen konvensional hanya memandang manusia sebagai makhluk ekonomi dan hanya memikirkan kebutuhan yang bersifat material saja. Tidak banyak mengungkapkan sisi-sisi kemanusiaan, perasaan atau kondisi psikologis, serta lingkungan sosial yang sangat berpengaruh terhadap kinerja manusia. Oleh karena itu, teori manajemen konvensional gagal mengatasi berbagai permasalahan terkait dengan hubungan antara karyawan dan perusahaan. Karyawan hanya dianggap sebagai makhluk lemah yang perlu memenuhi kebutuhan pokoknya, bukan sebagai aset perusahaan yang harus diutamakan. Pengusaha dan bawahannya memiliki perbedaan kepentingan, dan senantiasa terlibat dalam konflik yang tidak pernah terselesaikan, pihak penguasa yang sangat kuat mengeksploitasi karyawan yang memiliki posisi tawar yang lemah. ${ }^{1}$

Selain itu, teori-teori manajemen modern juga tidak mampu memberikan solusi terhadap bentuk penyimpangan perilaku individu organisasi yang tak beretika, misalnya praktik suap, korupsi, nepotisme,

\footnotetext{
${ }^{1}$ Abdul Halim Usman, Manajemen Strategis Syariah: Teori, Konsep, dan Aplikasi, (Jakarta: Zikrul Hakim, 2015), 31.
} 
eksploitasi dan komersialisasi jabatan, penyalahgunaan wewenang, keserakahan, ketidakadilan, dan sebagainya. Hal ini disebabkan karena teori manajemen konvensional hanya fokus pada variabel yang terdapat dalam lingkup internal manajemen, meliputi hubungan atasanbawahan, jenjang karir, dan promosi, perilaku anggota organisasi tanpa bersentuhan dengan variabel lingkungan eksternal yang berpengaruh secara kuat terhadap aktivitas internal manajemen. Tidak ada perhatian yang serius bagi manajemen terhadap lingkungan dan nilainilai sosial berupa adat, nilai, keyakinan serta etika yang dianut masyarakat.

Teori manajemen dalam praktiknya menerapkan metode yang bersifat parsial, yaitu hanya fokus pada produktivitas dan keuntungan material. IImu manajemen diaplikasikan sebagai alat kapitalisme untuk mengakumulasikan keuntungan saja. Manusia dianggap semata-mata sebagai makhluk ekonomi yang hidup demi menghasilkan uang. Sistem pengukuran kinerja manajemen senantiasa mengedepankan aspek profitabilitas yang bersifat material dan mentalitas hasil berjangka pendek. Ukuran keberhasilan dan kesejahteraan hanya ditandai dengan kemampuan organisasi menjadi mesin pengeruk uang, sementara aspek moralitas dan etika dalam bisnis dianggap tidak relevan. Oleh karena paradigma yang materialistik tersebut, teori manajemen konvensional cenderung mendorong organisasi untuk melakukan segala cara demi maksimalisasi laba. Bahkan Peter Drucker yang dikenal sebagai mahaguru manajemen, jauh-jauh hari telah memperingatkan agar tujuan manajemen bisnis harus difokuskan pada kepuasan pelanggan, bukan semata-mata mengejar keuntungan. $^{2}$

Beberapa pemikiran teoritis dan filosofis telah berusaha memberikan tawaran solusi untuk mengadaptasikan konsep manajemen strategis konvensional pada organisasi dakwah. Pemikiran-pemikiran ini sejalan dengan spirit Islamisasi ilmu pengetahuan yang digagas oleh Ismail Raji Al-Faruqi. Faruqi menganggap bahwa paradigma keilmuan konvensional yang bersifat sekuler bermuatan spirit etnosentrisme Barat yang sangat berbahaya. Karena itu, ilmu pengetahuan Barat harus dibongkar ulang, dan ditanamkan paradigma nilai-nilai dan orientasi Islam atau tujuan dakwah. Perlu dibangun paradigma alternatif bagi ilmu manajemen, khususnya manajemen strategis yang lebih manusiawi, lebih mengadaptasi nilai-nilai etis dalam Islam, dan secara metodologis lebih compatible untuk diterapkan pada konteks organisasi dakwah.

Paradigma etis adalah serangkaian normanorma atau nilai-nilai yang bersumber dari prinsip-prinsip ajaran Islam yang dijadikan landasan bagi pengembangan dakwah strategis, yaitu operasionalisasi dakwah yang dikelola dengan berbasis pada manajemen strategis. Sedangkan paradigma metodologis adalah serangkaian prinsip prosedural dalam proses analisis strategis yang menjadi landasan operasional dalam menjalankan dakwah strategis bagi organisasi dakwah. Tanpa adanya paradigma etis dan metodologis alternatif tersebut, maka kerangka kerja manajemen

2 Ibid., 32-35. 
strategis konvensional, bukan hanya menjadi materialis dan tidak humanis, melainkan juga tidak memiliki relevansi dengan kebutuhan organisasi dakwah. Karena pelaksanaan dakwah strategis sudah seharusnya memberikan dekonstruksi yang fundamental pada aspek nilai-nilai etis dan teknis metodologis pada kerangka kerja manajemen strategis. Sekadar menambahkan nilai-nilai etis yang normatif saja, tanpa menghadirkan perombakan prosedur-metodologis, hanya akan menjebak organisasi dakwah pada kerangka kerja yang parsial sebagaimana konsep manajemen strategis konvensional. Karena nilai-nilai etis yang sangat luhur tersebut hanya akan menjadi spirit normatif saja, tidak mampu menjelma dalam kerangka kerja operasional.

Oleh karena itu, studi ini ingin berkontribusi dalam mengembangkan sebuah paradigma etis dan metodologis bagi dakwah strategis secara komprehensif, dengan mengadaptasi konsep manajemen strategi konvensional pada ruang lingkup kerja organisasi dakwah. Ruang lingkup kajian dalam tulisan ini adalah: pertama, urgensi dan model penerapan kerangka kerja manajemen strategi bagi aktivitas dakwah; kedua, paradigma etis dalam model manajemen strategis syariah; dan ketiga, paradigma metodologis sebagai ancangan analitis dalam kerangka kerja dakwah strategis. Dari rumusan paradigma etis dan metodologis tersebut, diharapkan dapat menjadi ancangan teoritis dan sumber inspirasi bagi pengembangan kerangka kerja dakwah

\footnotetext{
3 David Hunger \& Thomas L. Wheelen, Manajemen Strategis, (Yogyakarta: Penerbit Andi, 2009), 2-3.

${ }^{4}$ Fred David, Manajemen Strategis : Konsep, (Jakarta: Salemba Empat, 2010), 11-13.
}

strategis yang lebih operasional di kemudian hari.

\section{Esensi Manajemen Strategi}

Untuk memahami dengan esensi manajemen strategis, maka perlu terlebih dahulu memahami bagaimana latar belakang kelahirannya, bagaimana konteks historis yang melahirkan studi tentang manajemen strategis. Studi tentang manajemen strategis muncul ketika terjadi peningkatan dinamika lingkungan organisasi, yaitu perubahan yang terjadi secara drastis dan sistemik. Dalam situasi ini, organisasi yang baik akan segera tertinggal jika gagal beradaptasi terhadap perubahan lingkungan tersebut, atau bahkan gagal menciptakan perubahan. ${ }^{3}$

Persoalan utama dalam studi manajemen strategis adalah bagaimana memperoleh dan mempertahankan keunggulan kompetitif, yaitu segala sesuatu yang dapat dilakukan dengan jauh lebih baik oleh organisasi dibandingkan dengan pesaing ${ }^{4}$. Proses manajemen strategis bertujuan untuk menempatkan organisasi secara optimal di lingkungan persaingannya dengan memaksimalkan antisipasi terhadap lingkungan dan tuntutan intern serta persaingan yang seringkali tak terduga. Penekanan utamanya pada peramalan lingkungan dan pertimbanganpertimbangan ekstern dalam merumuskan dan mengimplementasikan perencanaan ${ }^{5}$.

Dengan demikian, manajemen strategis adalah sebuah seni dan pengetahuan dalam

\footnotetext{
${ }^{5}$ John A. Pearce \& Richard B. Robinson, Manajemen Strategis: Formulasi, Implementasi, dan Pengendalian, Jilid 1, (Tangerang : Bina Rupa Aksara), 19.
} 
merumuskan, mengimplementasikan, serta mengevaluasi keputusan-keputusan lintas fungsional yang memampukan organisasi mencapai tujuannya ${ }^{6}$. Manajemen strategis adalah serangkaian keputusan strategis dan tindakan manajerial yang menentukan kinerja organisasi dalam jangka panjang, yang prosesnya meliputi pengamatan lingkungan internal dan eksternal, perumusan strategi berbasis peluang dan ancaman eksternal serta kekuatan dan kelemahan internal, implementasi dan pengendalian strategi. ${ }^{7}$

Dalam manajemen strategis, peran sebuah perencanaan strategis berada pada posisi yang sangat penting bagi manajer puncak organisasi. Sebab, perencanaan strategis menjadi sebuah alat manajemen untuk membantu organisasi memfokuskan visi dan prioritasnya sebagai jawaban terhadap lingkungan yang berubah dan untuk memastikan agar anggota-anggota organisasi bekerja ke arah tujuan yang sama. Perencanaan strategis adalah sebuah proses sistemik yang disepakati dan membangun keterlibatan di antara stakeholder utama tentang prioritas utama bagi misinya dan tanggap terhadap lingkungan operasi ${ }^{8}$.

Menurut Peter Drucker, tugas utama manajemen strategis adalah untuk mempertimbangkan misi dalam rangka menjawab pertanyaan "Apakah bisnis kita ini?". Tugas tersebut meliputi proses penetapan tujuan, pengembangan strategi, dan pengambilan keputusan saat ini untuk mencapai hasil pada masa mendatang, serta

${ }^{6}$ David, Manajemen Strategis., 5.

7 Hunger-Wheelen, Manajemen Strategis., 4.

8 Michael Allison \& Jude Kaye, Perencanaan Strategis Bagi Organisasi Nirlaba, (Jakarta: Yayasan Obor Indonesia, 2004), 1. dengan mengalokasikan sumber daya manusia dan keuangan untuk meraih hasilhasil utama ${ }^{9}$. Dalam hal ini, manajemen strategis akan membantu organisasi untuk beradaptasi secara efektif terhadap perubahan dalam jangka panjang. Karena itu organisasi harus mampu mengidentifikasi serta menyesuaikan diri dengan perubahan. Di samping itu, fungsi perencanaan strategis adalah untuk mempertajam fokus organisasi, agar semua sumber organisasi digunakan secara optimal untuk melayani misinya. ${ }^{10}$

Manfaat manajemen strategi bagi organisasi adalah memungkinkan organisasi merumuskan strategi terbaik melalui prosedur yang sistematis, logis, dan rasional. Selain itu, manajemen strategi juga memungkinkan organisasi untuk menentukan berbagai pilihan aksi dalam implementasi strategi melalui alokasi sumber daya seoptimal mungkin. Organisasi akan bertindak lebih produktif (tidak reaktif) dalam menghadapi masa depannya, serta mengarahkan aktivitas dan takdirnya sendiri. Dengan manajemen strategi, organisasi dapat menciptakan pemahaman dan komitmen bersama dari semua manajer dan karyawannya, sehingga mereka menjadi sangat kreatif dan inovatif jika memahami dan mendukung misi, tujuan, dan strategi organisasi. Dan pada akhirnya, manajemen strategi dapat membantu organisasi untuk menciptakan kesadaran akan ancaman eksternal dan pemahaman akan strategi pesaing, serta adaptasi pada perubahan. ${ }^{11}$

\footnotetext{
${ }^{9}$ David, Manajemen Strategis., 8.

${ }^{10}$ Allison \& Kaye, Perencanaan Strategis., 2.

${ }^{11}$ David, Manajemen Strategis., 23-25.
} 
Kerangka kerja manajemen strategis berdasarkan model yang diperkenalkan oleh David Hunger dan Thomas L. Wheelen ${ }^{12}$ terdiri atas beberapa tahap. Pertama, tahap pengamatan lingkungan, yaitu mengidentifikasi faktor-faktor strategis dari lingkungan internal dan eksternal yang terdiri atas unsur Strength, Weakness, Opportunity, dan Threat (SWOT). Kedua, tahap perumusan strategi, yaitu pengembangan rencana strategi jangka panjang berbasis pada hasil pengamatan lingkungan dengan melakukan evaluasi interaksi antar faktor strategis, menentukan misi, menentukan tujuan, merumuskan strategi untuk mencapai misi dan tujuannya, serta menentukan kebijakan dalam pengambilan keputusan organisasi. Ketiga, tahap implementasi strategi dalam bentuk tindakan pengembangan seperti membuat program, menentukan anggaran program, dan menyusun standard operating prosedur (SOP). Tahap terakhir adalah evaluasi dan pengendalian strategi, yaitu memonitor aktivitas organisasi dan membandingkan hasil kinerja dengan hasil yang diharapkan. Tahap-tahap manajemen strategis tersebut dapat dijelaskan melalui gambar model berikut:

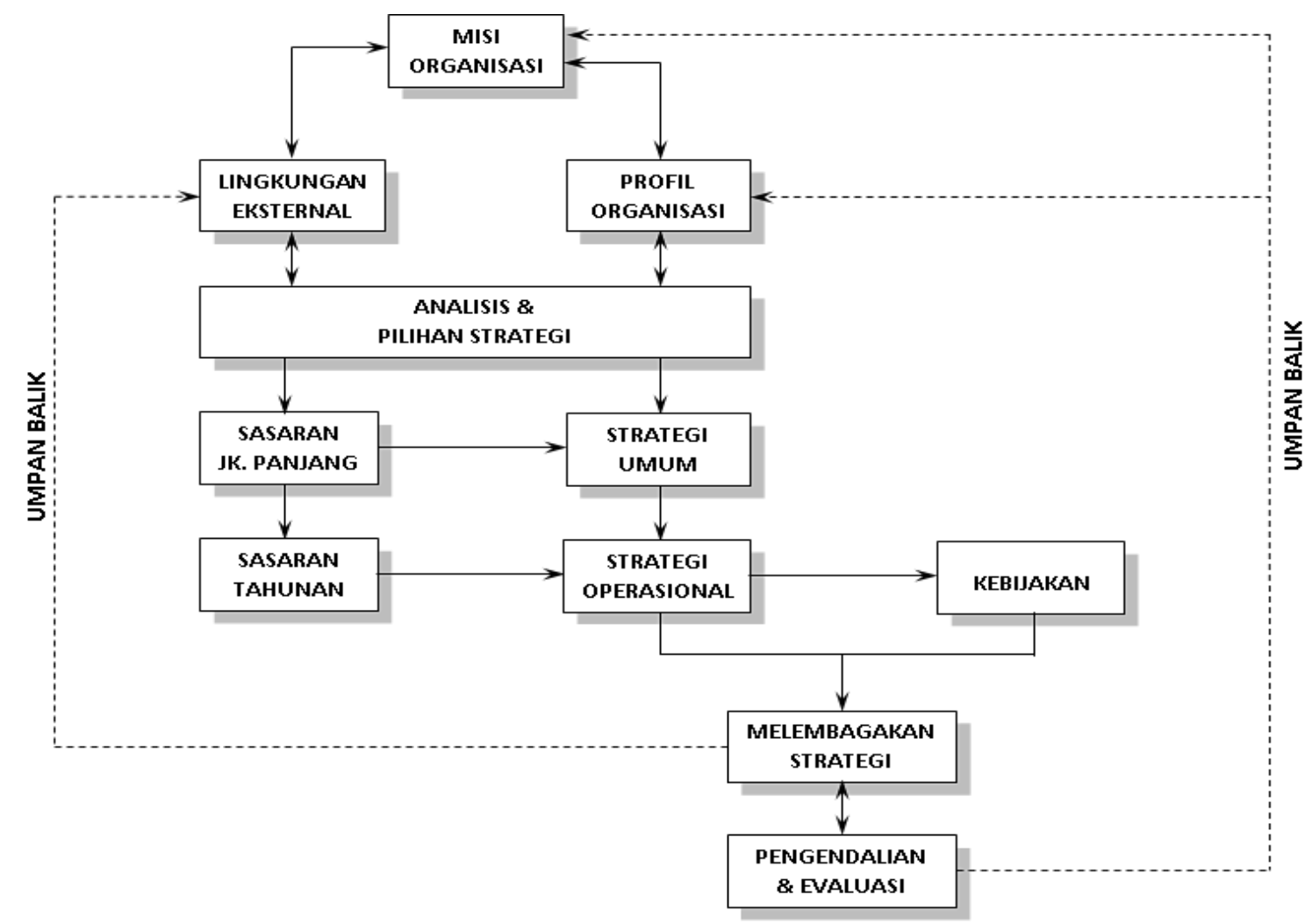

Sketsa 1 - Tahap-tahap Manajemen Strategis

\section{Esensi Organisasi Dakwah}

Organisasi dakwah adalah alat untuk menjalankan misi dakwah agar dapat mencapai tujuan yang telah ditentukan secara efektif dan efisien. Organisasi dakwah bisa disebut organisasi formal jika mengandung empat komponen berikut : (1) terdapat pembagian pekerjaan, karena jenis

\footnotetext{
12 Hunger-Wheelen, Manajemen Strategis., 9-19.
} 
dan jumlahnya tidak mungkin dikerjakan oleh satu orang saja; (2) penunjukan orangorang untuk mengerjakan setiap bagian pekerjaan berdasarkan kemampuan dan keahlian, (3) hubungan antara orang-orang yang melaksanakan pekerjaan menurut hierarki dan kewenangan, serta (4) sarana dan peralatan serta suasana dalam lingkungan organisasi yang saling mendukung secara sinergis. ${ }^{13}$

Sebaliknya, organisasi dakwah juga bisa berwujud organisasi informal, yaitu organisasi yang kehadirannya didasarkan pada ikatan persamaan tujuan, minat dan kepentingan, persamaan jenis, tempat dan pekerjaan, bahkan persamaan dalam menghadapi permasalahan. Organisasi dakwah yang bersifat informal ini banyak bermunculan di lingkungan perkantoran, kampus, sekolah, kompleks perumahan, bahkan di pasar-pasar seiring dengan berkembangnya tempat-tempat ibadah. Sebagai organisasi dakwah, tentu saja tujuan organisasinya adalah mengemban misi dakwah. Sehingga tujuan organisasi dakwah dapat diformulasikan sebagai upaya mengaktualisasikan nilai-nilai ajaran Islam dalam bentuk amar makruf nahi mungkar dan amal saleh dalam kehidupan seharihari, baik secara pribadi, keluarga, bermasyarakat, dan bernegara sehingga dapat mewujudkan masyarakat thayyibah yang sejahtera lahir dan batin serta berbahagia dunia dan akhirat. Tujuan tersebut adalah tujuan organisasi dakwah yang primer atau normatif yang berdimensi jangka panjang. Mungkin saja suatu organisasi dakwah memiliki tujuan-tujuan yang skala berjangka pendek atau sering disebut tujuan antara. Tujuan antara ini

13 Zaini Muchtarom, Dasar-dasar Manajemen Dakwah, (Yogyakarta: Al-Amin dan Ikfa), 16. biasanya adalah rumusan yang lebih sederhana, praktis, terukur dan merupakan operasionalisasi dari tujuan primernya. Misalnya, meningkatkan kesadaran akan nilai penting mengkaji Alquran beserta maknanya, meningkatkan kepekaan sosial, membantu meringankan beban fakir miskin, dan sebagainya.

Dalam perjalanan sejarah, kiprah organisasi dakwah telah menunjukkan peran yang sangat penting bagi kemajuan umat Islam. Para pelaku dakwah perlu untuk banyak mengambil hikmah dari pasang-surutnya peran organisasi dakwah sejak masa Nabi Muhammad, masa kekhalifahan, hingga masa modern dewasa ini. Dengan demikian, seluruh insan dakwah dapat mengevaluasi serta mempersiapkan diri untuk mengembangkan organisasi dakwah yang lebih baik, dalam arti lebih strategis, lebih efektif dan lebih efisien, pada masa-masa mendatang. Poin utama yang dapat dipelajari dalam kiprah dakwah Walisongo, sebagaimana juga dalam dakwah Rasulullah dan Khulafa Ar-Rasyidin, adalah strategi dakwah dan pengelolaan organisasi dakwah sangat dinamis dan berdimensi luas. Strategi dakwah bersifat sangat lentur dan adaptif terhadap lingkungannya yang dinamis. Pengelolaan organisasi dakwah juga mampu menghadirkan daya guna dan daya solutif dengan kebutuhan untuk menjawab problem pada masing-masing periode sejarahnya. Tidak ada pola yang selalu sama dalam semua aspeknya. Dakwah sejak masa Rasulullah tidak hanya berdimensi seruan secara verbal yang hanya mengandalkan model komunikasi satu arah dari seorang dai kepada mad'uw. 
Dakwah memiliki dimensi yang sangat luas, multidimensional, serba guna untuk menjawab berbagai kebutuhan atau persoalan hidup umat. Mulai dari masalah ibadah ritual, keimanan, hukum, hubungan sosial, kegiatan perekonomian, kekuasaan politik, hingga strategi perang, semuanya mendapatkan perhatian tanpa terkecuali. Dari perspektif metode dan pendekatan dakwah yang digunakan, juga memiliki variasi yang kreatif. Mulai dari pendekatan personal yang tertutup, komunikasi massa, pembinaan, pendidikan, pembentukan kader, penulisan kitab, pertunjukan seni, perdagangan, bantuan sosial, kerjasama politik, hingga pertempuran militer di medan perang. Berbegai media, strategi, dan pendakatan dakwah tersebut, pada hakikatnya memiliki tujuan yang sama, sebagaimana tujuan dakwah itu sendiri, yaitu untuk menyerukan, menanamkan, mengingatkan, meyakinkan tentang ajaran Islam sebagai nilai-nilai universal yang mampu memberikan rahmat bagi siapapun, kapanpun, dan di manapun.

Hal ini mengajarkan bahwa strategi dakwah dan pengelolaan organisasi dakwah harus selalu fleksibel untuk beradaptasi pada kebutuhan untuk menjawab setiap problematika sesuai konteks sosio historisnya. Organisasi dakwah harus sadar akan perubahan lingkungannya, dan secara sistematis mampu menyesuaikan diri dengannya. Manajemen organisasi dakwah harus memiliki sistem perencanaan strategis yang senantiasa mengapresiasi setiap dinamika kekuatan dan kelemahan internalnya, serta peluang dan ancaman lingkungan eksternalnya. Dengan demikian, strategi dan pendekatan dakwah yang dilakukan organisasi dakwah akan selalu aktual, memiliki daya guna dan daya solutif terhadap setiap problematika umat Islam di semua jaman.

\section{Urgensi Manajemen Strategi bagi Organisasi Dakwah yang Dinamis}

Semua makhluk hidup beserta lingkungannya akan mengalami transformasi, bukan hanya harus menerima fakta perubahan, bahkan harus mampu melakukan perubahan. Manusia wajib untuk melakukan perubahan pada dirinya dan lingkungannya, dari yang buruk menjadi baik, dari kegelapan menuju cahaya, dari kebiadaban menuju keadilan, dari jahiliyah menuju thayyibah. Perubahan adalah tujuan esensial bagi semua upaya dakwah. Dakwah dan perubahan adalah dua konsep yang saling membutuhkan dan menguatkan. Esensi dakwah adalah untuk melakukan perubahan dari jahiliyah menuju thayyibah. Dakwah tanpa perubahan adalah konsep yang absurd. Demikian juga, perubahan harus didorong, dipacu, dan diarahkan oleh dakwah, agar perubahan itu menjadi bermakna bagi mereka yang berubah. Oleh karena itu, sekali lagi perlu ditegaskan, bahwa dakwah harus selalu berdamai dengan perubahan, sebab perubahan adalah unsur imanen di dalam dirinya.

Manajemen strategis merupakan jawaban terhadap perkembangan yang kian tak terduga, kompleks, dan penuh kebaruan. Manajemen strategis ini merupakan jawaban atas tantangan masa depan yang penuh dengan ketakterdugaan, kompleks, dan penuh kebaruan. Manajemen strategis sendiri merupakan bagian dari fase perkembangan evolutif manajemen organisasi, sejalan dengan perkembangan 
yang terjadi pada lingkungan organisasi. ${ }^{14}$ Beberapa manfaat penerapan manajemen strategis adalah : (a) mampu mendeteksi masalah sebelum terjadi, (b) membuat para manajer/pimpinan menjadi lebih berminat terhadap organisasi, (c) membuat organisasi lebih responsif dan waspada terhadap perubahan, (d) mengarahkan segala upaya untuk menuju objektif organisasi, dan (e) merangsang munculnya kerjasama dalam menjawab permasalahan dan dalam memanfaatkan peluang. ${ }^{15}$

Dengan berbasis manajemen strategis, organisasi dakwah dapat selalu beradaptasi dengan setiap perubahan lingkungan, baik perubahan dalam lingkungan internalnya sendiri, maupun perubahan dari lingkungan eksternalnya. Strategi dakwah yang dilahirkan melalui kerangka kerja manajemen strategis, akan selalu aktual karena terus-menerus mampu merespon perkembangan. Karena itu, esensi dakwah strategi akan selaras dengan asas-asas ideal berikut, pertama, asas filosofis, yaitu strategi dakwah harus selaras dengan tujuan-tujuan yang hendak dicapai dalam proses atau aktivitas dakwah; kedua, asas kemampuan dan keahlian dai, yaitu strategi dakwah harus disusun berdasarkan pada kapasitas individu yang dimiliki oleh dai yang menjalankannya; ketiga, asas sosiologi, yaitu strategi dakwah harus bisa menyesuaikan dengan situasi dan kondisi dari sasaran dakwah (mad'uw) beserta karakter lingkungannya, misalnya politik pemerintahan setempat, mayoritas agama di daerah setempat, aspek filosofis, sosiokultural dari sasaran dakwah, dan

14 Anshoff, H. Igor dan McDonnell, Edward J., Implementing Strategic Management, 2nd ed., (NewYork: Prantice Hall, 1990), xv.

15 S.B. Hari Lubis, Pengantar Manajemen Strategi, (Bandung: TP, 1992), 1. sebagainya; keempat, asas psikologis, yaitu strategi dakwah harus berjalan dengan mempertimbangkan aspek kejiwaan manusia, baik sebagai subjek dakwah (dai) maupun sasaran dakwah (mad'uw). Karena seorang dai dan mad'uw adalah manusia yang memiliki karakter yang unik yang berbeda satu sama lainnya; dan terakhir, asas efektivitas dan efisiensi, yaitu strategi dakwah harus berusaha menyeimbangkan antara biaya, waktu maupun tenaga yang dikeluarkan dengan pencapaian hasilnya, bahkan kalau bisa waktu, biaya dan tenaga yang sedikit tetapi memperoleh hasil yang paling optimal.

Dengan demikian, manajemen strategis membantu organisasi dakwah berpijak ke bumi, berhadapan dengan kenyataan tentang diri dan lingkungannya. Organisasi dakwah harus menghapus paradigma bahwa dakwah adalah sebuah sistem yang tetap dan baku yang diwarisinya sejak masa kenabian. Desain dakwah bukanlah lagu lama yang terus-menerus diputar dan dipaksakan untuk didengar oleh sasarannya, hingga setiap orang merasa bosan dan kehilangan makna. Strategi, metode, media, dan bahasa dakwah harus selalu menyesuaikan dengan kapasitas organisasi dakwah dan karakter sasarannya. Agar setiap orang selalu merindukan kehadiran dakwah pada kehidupannya, karena ia mampu memberikan solusi dan ketenangan, bahkan hiburan yang edukatif.

Urgensi manajemen strategi bagi organisasi dakwah dapat dipahami dari beberapa alas an. ${ }^{16}$ Pertama, sebagaimana yang telah kita

16 Shofyan Affandy, Dakwah Strategis: Sebuah Ancangan Teoritis dan Filosofis, (Surabaya: Avvaterra, 2017), 167-172. 
pahami dalam sejarah dakwah Rasulullah dan para dai penerusnya, bahwa esensi dakwah adalah perubahan sosial yang multidimensional demi mewujudkan masyarakat yang lebih baik, adil dan seimbang. Dakwah adalah sebuah gerakan yang berdimensi sosial, meliputi berbagai aspek kehidupan tanpa terkecuali, sinergis dan terorganisir dengan menyatukan seluruh elemen gerakan masyarakat. Bukan hanya sebuah upaya individual yang parsial, semata-mata mengejar kepentingan tiap orang untuk mendapatkan keselamatan di dunia dan akhirat untuk dirinya sendiri, dan abai atas kerusakan sosial yang menjadi tanggung jawabnya. Sederhananya, dakwah adalah proyek sosial yang kompleks, karena tidak hanya merubah pola pikir dan perilaku individu, tetapi juga melakukan perubahan yang sistemik pada struktur kolektif masyarakat yang mencakup berbagai aspek kehidupan. Karena itu, proyek dakwah selaras dengan proyek pembangunan masyarakat yang membutuhkan pranata kelembagaan, sumber daya manusia dan modal yang berkualitas dan terkelola secara profesional. Tanpa manajemen yang rapi dan profesional, maka dakwah tidak akan menjadi sebuah gerakan kolektif seperti sebuah barisan yang sinergis, tapi hanya akan menjadi inisiatif-inisiatif parsial seperti gerombolan yang bekerja secara random dan terpecah-pecah dalam berbagai kepentingan yang sempit.

Kedua, dakwah strategis merupakan tuntutan logis untuk menjamin efektivitas dan efisiensi pencapaian tujuan dakwah, yaitu perubahan sosial untuk mewujudkan masyarakat yang baik dan seimbang. Karena gerakan dakwah membutuhkan arah yang jelas dan konsisten, bukan arah yang serba kabur, berubah-ubah, dan tercerai-berai dalam beragam tujuan yang berbeda. Dakwah strategis juga mensyaratkan pada organisasi dakwah agar memahami betul lingkungan internal dan eksternalnya, sehingga ia mampu menyadari kuantitas dan kualitas kekuatan, kelemahan, peluang dan ancaman yang dimilikinya. Sadar lingkungan ini akan membuat organisasi dakwah harus bisa bersikap fleksibel, selalu kontekstual, tidak berpikir ahistoris yang membuat dirinya 'ditolak' oleh lingkungannya sendiri. Sadar lingkungan ini juga akan membuat organisasi dakwah mampu 'mencair' mengikuti irama lingkungan, meskipun tetap harus berpegang pada visi dan misi utamanya. Karena itu, dengan menerapkan manajemen strategis, organisasi dakwah akan kreatif dan inovatif dalam merancang strategi dakwahnya, agar mudah diterima dan mendapatkan dukungan yang luas dari khalayak dakwah. Fleksibelitas strategi pesan dan media dakwah tersebut akan membuat proses dakwah menjadi lebih efektif, efisien, dan tentu saja ramah lingkungan. Artinya, pesan dakwah akan lebih mudah dicerna oleh kapasitas khalayak dakwah, nilai-nilai Islam lebih mudah dihayati dan dipraktikkan, lebih jauh, dakwah Islam akan bisa berjalan secara berkesinambungan, dari generasi ke generasi, hingga beberapa abad lamanya. Meskipun Rasulullah dan Walisongo tidak mengenal konsep tentang teori manajemen strategis, tapi prinsip-prinsipnya telah dipahami dengan baik dan dipraktikkan secara natural dengan caranya masingmasing. Pelajaran yang seharusnya diambil oleh organisasi dakwah pada masa sekarang adalah strategi dakwah harus bergerak fleksibel sesuai dengan konteks situasionalnya, bukan malah mengadopsi semua strategi dakwah Rasulullah atau 
Walisongo secara taken for granted. Artinya, strategi dakwah Rasulullah dan strategi dakwah Walisongo adalah strategi terbaik yang lahir dari proses adaptasi dengan kondisi lingkungan dakwah saat itu. Perubahan-perubahan strategi dakwah yang dilakukan Rasulullah dalam setiap periode dakwah yang berbeda juga merupakan respon strategis atas dinamika lingkungan yang terus bergerak. Jika seluruh umat Islam pasca Rasulullah hingga saat ini menerapkan strategi dakwah Rasulullah secara kaku, tekstual, dan mengabaikan dinamika lingkungan pada masanya, maka bisa dipastikan bahwa strategi tersebut akan kehilangan kompatibilitasnya dengan realitas. Konsekuensinya adalah pesan dakwah menjadi sulit dicerna, dianggap tidak lagi relevan, dan tidak mampu menjawab masalah masyarakat pada jamannya.

Ketiga, kegagalan dalam menerapkan dakwah strategis, akan membuat program dakwah menjadi tumpul, tidak efektif, seperti sebuah usaha untuk menggarami lautan yang tidak akan pernah menghasilkan dampak perubahan seperti yang diharapkan. Bahkan, kegagalan dalam menerapkan dakwah strategis akan berbalik menjadi kontraproduktif, alih-alih mendorong perubahan yang positif, justru menimbulkan kerusakan yang bertentangan dengan tujuan dakwah itu sendiri. Dakwah yang tidak berbasis pada manajemen strategis akan kehilangan orientasi, bergerak secara acak, spontan, reaktif, dan tentu juga akan sulit diukur tingkat efektivitasnya. Jika kehilangan orientasi ini dialami oleh sebagian besar organisasi dan insan dakwah, maka secara keseluruhan gerakan dakwah akan berjalan layaknya kapal besar hanya terombang-ambing di lautan tanpa tahu arah daratan yang dituju. Maka tentu saja, dakwah bukan hanya menjadi tidak efektif, tapi juga akan memunculkan kekacauan dan kerusakan yang sistemik. Hal ini mengakibatkan program dakwah menjadi mandul, tidak mampu berkontribusi sebagai solusi bagi kerusakan masyarakat, justru menjadi sumber bagi masalah masyarakat yang harus disembuhkan terlebih dahulu.

Kegagalan dalam menerapkan dakwah strategis juga bisa terjadi ketika organisasi dan program dakwahnya tidak mampu memahami kapasitas diri dan kondisi lingkungan dakwah yang dihadapinya. Sehingga strategi dakwah yang dilakukan tidak selaras dengan kapasitasnya sendiri atau bertentangan dengan karakter lingkungan dakwahnya. Strategi dakwah yang tidak selaras dengan potensi kekuatan diri dan kelemahan yang dimiliki, akan menjadi strategi yang baik dalam rencana, tapi buruk atau bahkan mustahil dalam aplikasinya. Organisasi dakwah gagal memberdayakan potensi sumber dayanya secara tepat guna, sehingga hasil yang dicapai menjadi tidak optimal atau tidak mungkin bisa tercapai jika terlalu memaksakan diri. Sedangkan strategi dakwah yang tidak selaras atau bahkan bertentangan dengan karakter serta preferensi khalayak dakwah yang dihadapi, akan memunculkan resistensi, apatisme, atau penolakan, baik secara halus maupun dengan cara kekerasan. Butuh cara-cara yang cerdas, kreatif dan inovatif untuk menciptakan daya tarik terhadap masyarakat terhadap produk-produk dakwah yang ditawarkan. Salah satu daya tariknya, tentu saja, adalah kemampuan produk dakwah tersebut dalam memecahkan masalah dan kebutuhan 
masyarakat akan kemaslahatan yang bersifat komprehensif. Artinya, organisasi dakwah harus mampu menghadirkan sebuah produk yang solutif dan mempromosikannya secara komunikatif, sehingga produk tersebut jadi mudah dipahami dan diaplikasikan secara meyakinkan. Dalam hal ini, manajemen strategi dakwah akan mengaplikasikan prinsip-prinsip pemasaran dakwah. Dalam pemasaran dakwah, sebuah produk dakwah harus mampu mengonversikan nilai-nilai dakwah menjadi solusi untuk menjawab kebutuhan khalayak dakwah.

\section{Implementasi Manajemen Strategis dalam Dakwah Nabi}

Implementasi kerangka manajemen strategis secara nyata dalam dakwah, dapat ditelaah dari sejarah hijrah Rasulullah, sebagaimana yang diuraikan oleh Ahmad Abdul 'Adhim Muhammad dalam buku Strategi Hijrah: Prinsip-prinsip IImiah dan Ilham Tuhan (2004). Rasulullah telah merumuskan berbagai strategi dan program untuk mencapai tujuan dari hijrah, yaitu untuk membentuk daulah Islamiyah yang tercermin dalam bentuk nilai-nilai tauhid, menghapuskan karakter jahiliyah, dan transformasi manusia dari kegelapan atau kebodohan. ${ }^{17}$

Secara strategis, hijrah Nabi Muhammad dan umat Islam dari Mekkah ke Madinah dilakukan untuk mencari tempat yang baik dan tepat untuk mewujudkan masyarakat Islami dengan jalan menyelamatkan umat Islam dari kekejaman kaum kafir Quraisy, serta menyediakan lingkungan yang

\footnotetext{
${ }^{17}$ Ahmad Abdul 'Adhim Muhammad, Strategi Hijrah: Prinsip-prinsip Ilmiah dan Ilham Tuhan, (Solo: Tiga Serangkai, 2004), 14-15.
}

memberikan kenyamanan kepada mereka agar dapat menjaga agama, serta menjauhkan diri dari fitnah ${ }^{18}$. Selain itu, hijrah juga bertujuan untuk menyediakan jalan keluar agar terbebas dari belenggu dan ikatan yang mengekang upaya dakwah, sehingga umat Islam memiliki kebebasan bergerak dalam melakukan dakwah Islamiyah. Tetapi hijrah bukanlah upaya melarikan diri karena ketakutan dari siksaan, melainkan untuk menunaikan misi mulia sebagai bagian dari strategi perluasan dakwah.

Berdasarkan pada tujuan hijrah tersebut, maka Rasulullah kemudian melakukan beberapa strategi untuk mewujudkannya. Langkah pertama yang diambil oleh Rasulullah adalah melakukan hijrah gelombang pertama ke Habasyah. Dalam hal ini Rasulullah berkata: "Jika kalian meninggalkan kota ini menuju negeri Habasyah, sesungguhnya di sana ada seorang raja. Di sisinya, tak seorang pun akan didzalimi. Negeri itu adalah daratan kebenaran sehingga Allah SWT menjadikan negeri tersebut sebagai tempat berlindung bagi kalian"19.

Dari kalimat tersebut, terlihat dengan jelas, bahwa Rasulullah memiliki sebuah pertimbangan strategis dengan melibatkan prediksi yang akurat dalam memberikan perintah untuk berhijrah ke Habasyah, dan bukan ke tempat-tempat yang lain. Secara tersirat, dapat disimpulkan bahwa Rasulullah telah melakukan penelitian yang cermat dengan melakukan analisis perbandingan untuk menentukan alternative tempat tujuan hijrah yang paling

\footnotetext{
18 lbid., 21-23.

${ }^{19}$ Dirujuk oleh Ahmad Abdul 'Adhim Muhammad dari Sirah Nabawiyah karya Ibnu Hisyam.
} 
tepat dan menguntungkan. Salah satu pertimbangan politis yang paling penting adalah karakter kepemimpinan yang bijaksana yang dapat melindungi umat Islam yang akan hijrah ke negerinya. Sehingga, strategi dakwah Rasulullah dibangun berdasarkan fakta-fakta dan melalui proses analisis yang ilmiah. Selain itu, Rasulullah juga menerapkan strategi hijrah ke Habasyah dengan strategi perjalanan secara rahasia agar tidak diketahui oleh kaum kafir Quraisy yang akan berpotensi untuk mengganggu atau melarang pelaksanaan hijrah. Selain itu, hijrah harus dilakukan dalam rombongan yang kecil dan tidak melalui daerah yang luas, agar tidak menarik perhatian kaum musyrik. ${ }^{20}$

Demikian juga yang dapat kita pelajari dari strategi hijrah umat Islam ke Thaif sebagai salah satu alternatif tempat dakwah baru, selain Habasyah dan Mekkah. Thaif secara geopolitik memiliki posisi yang lebih strategis daripada Habasyah, karena wilayahnya sangat terbuka dari segala penjuru. Selain itu, secara ekonomis, Thaif adalah produsen hasil pertanian yang sangat melimpah dan menjadi salah satu sumber utama penyuplai bahan makanan ke Mekkah. Sedangkan pertimbangan politisnya adalah kabilah Tsaqif di Thaif yang merupakan musuh bebuyutan bagi kaum Quraisy dalam bidang agama dan perdagangan. Sehingga rivalitas yang tajam antara kabilah Tsaqif dan kaum Quraisy ini dapat menguntungkan kepentingan umat Islam yang sedang menghadapi konflik dengan kaum Quraisy Mekkah. Dari sini dapat dilihat bahwa strategi hijrah ke Thaif juga melalui pertimbangan-pertimbangan yang cermat, akurat, dan ilmiah, untuk mengambil keputusan yang terbaik dari berbagai bidang.

Hal yang sama juga bisa kita pelajari dari strategi hijrah umat Islam yang terakhir, yaitu ke Madinah. Secara geografis, Madinah memiliki berbagai keistimewaan dibandingkan tempat-tempat lain dalam upaya menjalankan dakwah secara internasional. Karena Madinah memiliki tanah yang sangat subur, banyak tumbuh pohon kurma, iklimnya normal, dan menyediakan banyak sumber air yang jernih dan melimpah. Penduduk asli Madinah juga memiliki garis keturunan dari bangsa Arab, yaitu dari kaum Imalaqah atau Al-Amaliq, sebelum kemudian muncul para pendatang kabilah Yahudi dari Palestina dan kabilah Yaman yang terdiri atas suku Aus dan Khazraj. Rasulullah sendiri memiliki hubungan silsilah kekerabatan dan persaudaraan dengan Banu Najjar di Madinah yang merupakan paman dari ayah beliau.

Dalam mempersiapkan diri untuk melakukan hijrah, Rasulullah telah merancang berbagai strategi pendahuluan yang sangat sistematis yang terbagi pada beberapa tahap. Pertama, melakukan hubungan komunikasi dakwah kepada rombongan para pembesar dari Madinah yang memiliki kedudukan tinggi dan sangat dihormati yang sedang melakukan ibadah haji ke Mekkah. Nabi secara sengaja memilih segmen tertentu dari jamaah haji untuk dijadikan sebagai mitra dakwah, yaitu para pemimpin rombongan dari Madinah, baik dari suku Aus maupun Khazraj, terutama yang mengenal dengan baik ajaran Yahudi. Karena ajaran kaum Yahudi

${ }^{20}$ Ibid., 25. 
memiliki afirmasi terhadap hadirnya seorang nabi baru yang telah dijanjikan.

Kedua, Rasulullah melakukan baiat di Aqabah bersama penduduk Madinah yang sedang beribadah haji yang telah mengimani kerasulan Muhammad setelah menerima dakwah Rasulullah. Baiat Aqabah ini dilaksanakan dengan strategi yang jitu dan sangat rahasia dengan menetapkan tempat dan waktu yang tepat, agar dapat menjamin keamanannya. Sehingga sebelum melakukan hijrah, Rasulullah telah membangun fondasi awal yang kokoh dengan mengikat janji melalui baiat bersama penduduk Madinah. Selain itu, Rasulullah telah menciptakan sebuah primordialisme baru dikalangan suku Aus dan Khazraj yang sering bertikai, melalui ikatan persamaan berbasis pada keimanan, serta melunturkan sikap kesukuan. Ketiga, Rasulullah melakukan pembinaan dakwah secara intensif dengan mengutus Mush'ab bin Umar untuk menyiarkan Alquran dan pemahaman agama Islam kepada penduduk Madinah yang telah mengikuti baiat Aqabah. Dari sini, penganut Islam semakin meluas di antara berbagai suku yang tinggal di Madinah, dan mereka siap untuk menyambut dan menerima kehadiran Rasulullah ketika berhijrah ke Madinah. Dalam hal ini Rasulullah pernah bersabda: "Sesungguhnya Allah telah menyiapkan sanak saudara dan negeri buat kalian sebagai tempat bernaung"21

Keempat, Rasulullah memilih hijrah pada momentum yang sangat tepat, rencana pembunuhan terhadap Rasulullah telah dirancang secara matang oleh kaum kafir Quraisy. Strategi untuk mengelabui kaum

\footnotetext{
${ }^{21}$ Dirujuk oleh Ahmad Abdul 'Adhim Muhammad dari
} Sirah Nabawiyah karya Ibnu Hisyam. kafir Quraisy telah dipersiapkan oleh Rasulullah secara matang dengan terlebih dahulu berkoordinasi bersama Abu Bakar di waktu yang tepat, serta meminta Ali bin Abi Thalib untuk tidur di ranjang Rasulullah. Sehingga seluruh pergerakan Rasulullah pada saat melaksanakan hijrah di sepertiga malam tidak terdeteksi oleh kaum kafir Quraisy. Kelima, Rasulullah memilih jalur perjalanan hijrah ke Madinah melalui rute yang tidak biasanya dilalui dan mengambil arah yang berlawanan, yaitu menuju ke Gua Tsur. Strategi ini dilakukan untuk mengecoh kaum kafir Quraisy yang akan mengejar Rasulullah yang dalam perjalanan menuju Madinah. Selama tiga hari di dalam Gua Tsur, telah dirancang jalur suplai logistik melalui peran Asma, puteri Abu Bakar. Amir bin Fuhirah bertugas untuk menggiring ternaknya pada jalur hijrah Rasulullah agar dapat menghilangkan jejak. Sedangkan Abdullah bin Uraiqit bertugas sebagai penunjuk jalan yang amanah dan sangat kompeten.

Keenam, Rasulullah melakukan negosiasi yang cerdik selama menghadapi ancaman dalam perjalanan hijrah, khususnya adalah ketika menghadapi Suraqah bin Malik yang mengancam akan membunuh Rasulullah demi mendapatkan hadiah seratus ekor unta. Rasulullah berhasil menghadapinya dengan sebuah janji bahwa suatu ketika Suraqah akan mengenakan gelang Kisra yang sangat mulia. Ketujuh, sesampainya di Madinah, Rasulullah melakukan berbagai upaya strategis yang sangat penting bagi pembangunan komunitas umat Islam yang kokoh yang terbentuk dari berbagai suku dan latar belakang keyakinan yang beragam. Di antara yang telah dilakukan oleh 
Rasulullah untuk membangun Daulah Islamiyah adalah dengan jalan membangun masjid sebagai pusat kegiatan, menyatukan atau membangun ikatan persaudaraan antara kaum Muhajirin dan Anshar, meletakkan dasar-dasar konstitusional yang demokratis, serta membangun landasan sistem ekonomi Islam yang adil.

Dari sini, bisa disimpulkan bahwa Rasulullah telah melakukan sebuah perencanaan strategis yang sistematis, ilmiah, melalui proses-proses kalkulasi yang cermat dan berbasis pada fakta-fakta yang akurat. Setidaknya, Rasulullah pasti menjalankan beberapa tahap perencanaan strategis yang meliputi upaya mempelajari situasi dan perkembangannya serta menyusun prediksi-prediksi yang mungkin akan terjadi. Kemudian mengidentifikasi berbagai peluang yang tersedia agar dapat dimanfaatkan untuk mencapai tujuan. Dilanjutkan dengan tahap menentukan program kerja dan pembagian tugas yang jelas dan bernilai strategis.

Jika dipahami dalam perspektif ilmu manajemen strategis, maka strategi hijrah yang dilakukan oleh Rasulullah tersebut memiliki kerangka ilmiah yang mengandung karakter berikut: (1) memiliki target yang jelas, yaitu untuk mencari tempat perlindungan dan keleluasaan dalam menjalan tugas dakwah; (2) strategi dibangun berdasarkan pada data atau informasi dan pengalaman yang sangat akurat; (3) pemilihan tempat dan momentum yang sangat tepat dengan mempertimbangkan berbagai kondisi dan prediksi; (4) fleksibelitas dalam menghadapi situasi yang terus mengalami perubahan; (5) membangun konsistensi dan soliditas sumber daya manusia dalam menjalankan tugasnya sesuai skenario yang telah direncanakan; dan yang terakhir, (6) membangun sikap mental yang tangguh, berani menghadapi segala risiko yang mungkin terjadi, demi mencapai tujuan.

Sehingga sangat mudah untuk disimpulkan bahwa, penerapan manajemen strategis untuk upaya menjalankan misi dakwah adalah suatu keniscayaan, sebagaimana yang telah dicontohkan oleh Rasulullah dalam peristiwa hijrah di atas. Tentu saja, dalam konteks yang lain, misalnya dalam mengatur pasukan untuk memenangkan suatu peperangan, merumuskan desain pesan dan saluran komunikasi dakwah, hingga dalam membangun berbagai aspek kehidupan pada konteks Daulah Islamiyah, Rasulullah juga selalu menerapkan pola pikir perencanaan strategis. Hal ini bisa dengan cermat diuji atau dipelajari melalui tinjauan sejarah politik masa kenabian.

\section{Manajemen Strategis untuk Organisasi Dakwah}

Berkembangnya teori manajemen strategis syariah telah mencoba menerapkan pendekatan Islami dengan melakukan langkah-langkah koreksi, kemudian adisi dan internalisasi nilai-nilai Islam/syariat ke dalam teori manajemen strategis konvensional. Model dan teori manajemen strategis syariah mencoba memasukkan karakter-karakter bisnis yang berasaskan Islam (tauhid), seperti pilihan strategi yang bernilai maslahat buat umat, konsepkonsep kemitraan (mudharabah, musyarakah), persaudaraan (ukhuwah), berlomba dalam kebajikan (fastabiqul khairat), serta pertimbangan halal-haram, dosa-pahala, orientasi mencapai keberkahan dan ridha Allah (mardhatillah), 
guna mencapai kebahagiaan dunia dan akhirat secara simultan, menjadi landasan moral, ideologis, dan semangat pendorong (motivasi) dalam mengelola sebuah organisasi. $^{22}$

Salah satu poin kritik dari para penggagas manajemen strategi syariat terhadap model manajemen strategis konvensional adalah dalam pada tahap pengendalian dan evaluasi dari strategi. Jika dalam pelaksanaannya strategi yang dipilih dan ditetapkan ternyata tidak dapat dilaksanakan dengan maksimal, maka penyusunan strategi harus memberikan umpan balik (feedback) mulai dari awal formulasi strategi, bahkan harus mengevaluasi kembali visi, misi, dan tujuan organisasi. Bisa jadi, dalam proses feedback tersebut diperoleh kesimpulan bahwa organisasi harus merubah visi dan misinya, atau merubah target sasaran dan tujuan organisasi. Tentu saja, bukanlah perkara mudah untuk membongkar kembali visi, misi, dan tujuan organisasi hanya karena kegagalan dalam implementasi strategi. Karena telah banyak investasi modal, waktu dan energi dan berbagai sumber daya organisasi lainnya yang sudah terlanjur dikeluarkan dalam mengimplementasikan strategi. Terkesan kerangka kerjanya menjadi tidak efisien karena berbasis pada upaya coba-coba atau spekulasi yang tidak jelas hasilnya.

Kritik yang lain, teori manajemen strategis konvensional dianggap tidak mampu menunjukkan secara tegas tentang sesuatu yang menjadi motivasi SDM organisasi,

\footnotetext{
22 Abdul Halim Usman, Manajemen Strategis Syariah: Teori, Konsep \& Aplikasi, (Jakarta: Zikrul Hakim, 2015), 24.

23 Ibid., 56-57.
}

motivasi berupa nilai material ekonomi atau orientasi kemanusiaan. Kepatuhan SDM organisasi pada ketentuan manajemen disebabkan karena struktur kepemimpinan serta kekuasaan, atau karena alasan nilai sosial dan etika. Tetapi yang bisa dipastikan, bahwa kepatuhan SDM organisasi tidak dikaitkan sama sekali dengan motif-motif agama atau spiritual. Sehingga, teori manajemen strategi konvensional dianggap masih belum mampu memberikan solusi terhadap masalah penyimpangan perilaku SDM organisasi. Hal inilah yang dianggap sebagai penyebab tidak maksimalnya hasil pencapaian dari manajemen strategi konvensional, karena selalu mengabaikan nilai penting faktor spiritual dalam semua aspek, mulai dari visi dan misi yang hanya berorientasi dunia semata (profit dan benefit), penetapan strategi yang terkadang masih menghalalkan segala cara, atau masih menggunakan strategi persaingan bisnis yang sering dilakukan dengan menyingkirkan atau mematikan pesaing dalam bisnis agar dirinya muncul sebagai pemenang. $^{23}$

Dalam menjawab beberapa kelemahan dari manajemen strategi konvensional tersebut, maka diperlukan sebuah upaya terobosan teoritis untuk merumuskan sebuah manajemen strategi alternatif yang berbasis pada perspektif syariat. Yusanto dan Widjajakusuma ${ }^{24}$, menyatakan bahwa manajemen strategis perspektif syariat setidaknya memiliki sembilan aspek yang membedakannya dengan manajemen strategis konvensional, yaitu: (1) asas, (2) motivasi, (3) orientasi, (4) strategi induk, (5)

\footnotetext{
${ }^{24}$ M.I. Yusanto dan M.K. Widjayakusuma, Manajemen Strategis Perspektif Syariah, (Jakarta: Khairul Bayaan, 2003).
} 
strategi fungsional operasi, (6) strategi fungsional keuangan, (7) strategi fungsional pemasaran, (8) strategi fungsional SDM, dan (9) sumber daya. Sebagai kaidah berpikir, tauhid dan syariat difungsikan sebagai asas atau landasan pola pikir, sedangkan sebagai kaidah amal, syariat difungsikan sebagai tolok ukur dalam kegiatan organisasi. Dalam hal ini, konsep manajemen strategi konvensional harus dilakukan koreksi dan internalisasi nilai-nilai Islam ke dalamnya. Sehingga, nilai-nilai Islam ini akan menjadi payung bagi perumusan strategi dan taktik dalam seluruh aktivitas organisasi. Implementasi manajemen strategi dengan kendali syariat akan membawa organisasi bisnis mencapai empat hal utama: (1) target hasil berupa profit material dan manfaat nonmaterial, (2) pertumbuhan yang terus meningkat, (3) keberlangsungan dalam kurun waktu yang lama, dan (4) keberkahan dan keridhaan Allah. Manajemen strategis syariah harus dilengkapi dengan sinergitas antara kepemimpinan, struktur, kultur, etika, dan tawakal kepada Allah, agar dapat memberikan hasil yang bernilai (tangible) dan berkelanjutan (sustainable).

Menurut Abdul Halim Usman, manajemen strategis syariah memiliki empat karakter khas yang membedakannya dengan manajemen strategis konvensional, yaitu:
(1) asas tauhid, (2) orientasi duniawiukhrawi, (3) motivasi mardhatillah, dan (4) strategi dan implementasi berbasis syariat. Sehingga manajemen strategis syariah dapat didefinisikan sebagai berikut: rangkaian proses aktivitas manajemen Islami yang mencakup tahapan formulasi, implementasi, dan evaluasi strategi untuk mencapai tujuan organisasi, nilai-nilai Islam menjadi landasan strategis dalam seluruh aktivitas organisasi, yang diwarnai oleh asas tauhid, orientasi duniawi-ukhrawi dan motivasi mardhatillah. ${ }^{25}$

Sejak proses penetapan visi, misi, dan tujuan, harus telah dilakukan internalisasi dan adisi nilai-nilai Islam, yaitu asas tauhid, orientasi duniawi-ukhrawi, dan motivasi mardhatillah. Pada tahap formulasi strategi hingga implementasinya senantiasa dalam koridor nilai-nilai etika dan syariat, seperti pertimbangan halal-haram, dosa dan pahala, serta sistem kerja sama bisnis yang nonribawi disertai dengan organisasi dan kepemimpinan yang profesional dan berakhlakul karimah. Dari sisi pengendalian dan evaluasi, diwarnai oleh self-evaluation berupa perilaku ihsan dan perilaku takwa dan tanggung jawab ilahiah, sehingga melahirkan kinerja terbaik bagi organisasi. Model manajemen strategis syariah dapat digambarkan sebagai berikut: ${ }^{26}$

25 Usman, Manajemen Strategis Syariah., 62-63.

${ }^{26}$ Ibid., 63. 


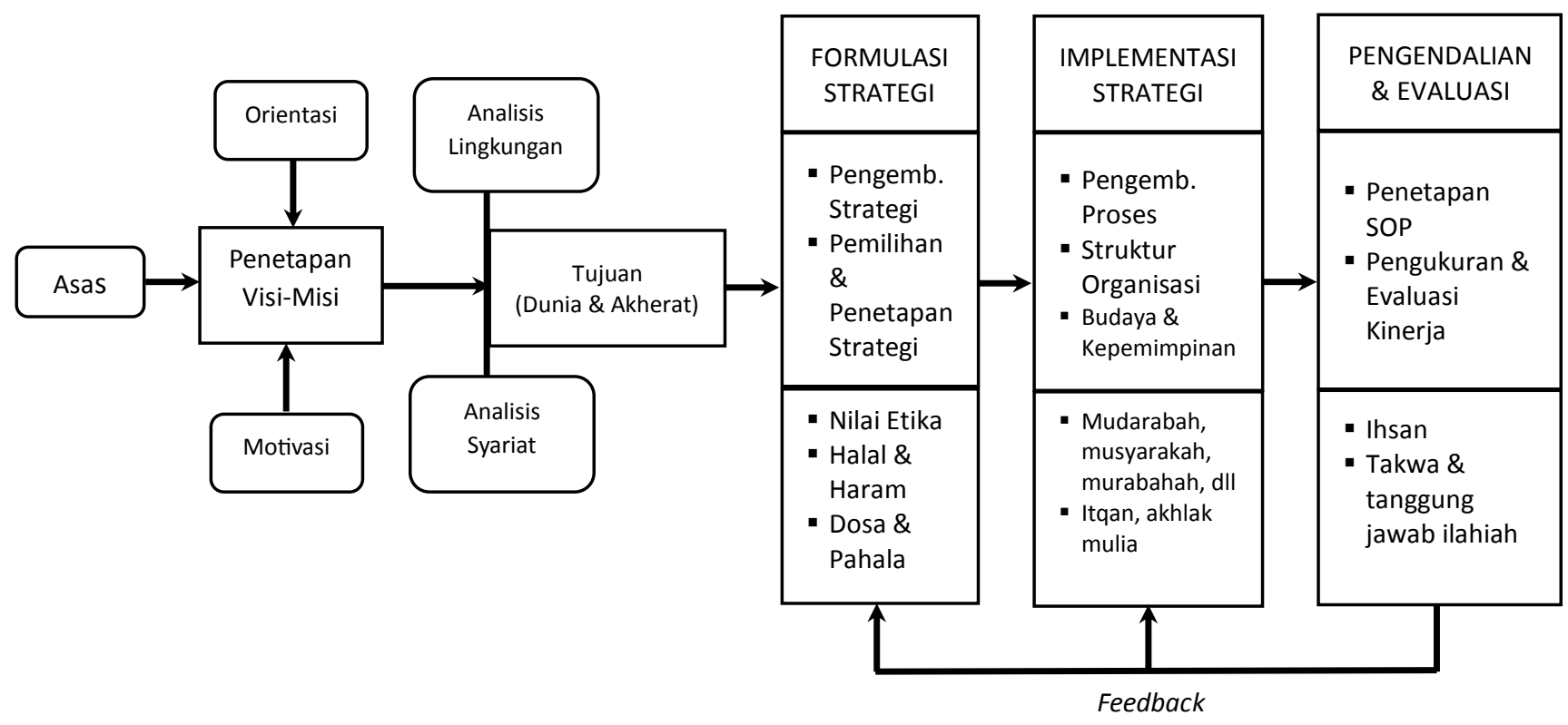

Sketsa 2: Model Manajemen strategis syariah

Penerapan prinsip-prinsip syariat dalam manajemen strategis akan terlihat pada muatan isi strategi induknya yang mencakup visi, misi dan tujuan organisasi. Bagi organisasi yang menerapkan manajemen strategis syariah, pilihan strategi induknya tidak akan hanya berorientasi dunia tetapi hingga akhirat. Pernyataan visi, misi dan tujuan organisasi berbasis syariat harus berbasis pada hakikat penciptaan manusia sebagai khalifah Allah di muka bumi dan misi Islam sebagai rahmat bagi seluruh alam, serta memperhatikan tujuan hidup manusia untuk meraih kebahagiaan hidup di dunia maupun di akhirat.

\section{Paradigma Etis Bagi Dakwah Strategik}

Tidak bisa dipungkiri bahwa manajemen strategis adalah sebuah keniscayaan dan keharusan bagi organisasi dakwah dalam mewujudkan tujuan dakwahnya melalui gerakan perubahan sosial. Karena itu perlu upaya yang serius dan ilmiah untuk mengadaptasikan prinsip-prinsip teoritis dan kerangka kerja aplikatif manajemen strategis pada organisasi dakwah. Persoalannya adalah bagaimana merancang sebuah kerangka kerja teoritis dan praktis dalam tradisi ilmu manajemen konvensional menjadi kompatibel dengan konteks organisasi dakwah yang memiliki karakter khusus dan bergerak di bidang nonkomersial.

Beberapa pemikiran teoritis dan filosofis muncul sebagai tawaran solusi untuk mengadaptasikan manajemen strategis konvensional pada organisasi dakwah. Pemikiran-pemikiran inovatif yang berkembang kemudian berada pada spirit yang sejalan dengan Islamisasi ilmu pengetahuan, sebagaimana yang telah digagas oleh Ismail Raji Al-Faruqi dalam bukunya Islamization of Knowledge: General Principle and Workplan (1982). Faruqi berpandangan bahwa paradigma keilmuan yang berkembang saat ini bukan hanya bersifat sekuler, melainkan juga bermuatan 
dengan etnosentrisme Barat yang sangat berbahaya jika dipraktikkan. Karena semua disiplin ilmu dari Barat perlu untuk disusun ulang, diberikan pendasaran nilai-nilai dan orientasi keislaman yang baru.

Selain itu, Yusanto dan Widjayakusuma (2002) juga menawarkan gagasan metode Islamisasi ilmu pengetahuan yang mencakup lima langkah berikut: ${ }^{27}$ (1) internalisasi, yaitu melakukan proses pemasukan nilai-nilai Islam ke dalam materimateri sehingga sesuai dengen pemikiran, pendapat, dan hukum Islam; (2) koreksi, yaitu melakukan koreksi penggantian terhadap materi-materi yang bertentangan dengan pemikiran, pendapat, dan hukum Islam; (3) substitusi, yaitu melakukan penggantian terhadap materi-materi yang bertentangan dengan pemikiran, pendapat, dan hukum Islam dengan materi yang baru sama sekali; (4) adisi, yaitu menambahkan submateri baru dalam materi yang sudah ada; dan (5) fiksasi, yaitu pembakuan materi yang sudah ada.

Dalam kerangka disiplin ilmu manajemen strategi, Abdul Halim Usman dalam bukunya Manajemen Strategi Syariat: Teori, Konsep dan Aplikasi (2015) juga telah menawarkan sebuah konsep tentang manajemen strategis yang berbasis syariat. Konsep ini mencoba untuk menerapkan metode internalisasi, koreksi, dan adisi sebagaimana yang diusulkan oleh Yusanto dan Widjayakusuma, untuk merumuskan gagasan model manajemen strategis syariah. Meskipun secara umum, kerangka kerja manajemen strategis konvensional tidak dibongkar secara fundamental, tetapi model yang ditawarkan oleh Abdul Halim

27 Yusanto dan Widjajakusuma, Menggagas Bisnis Islami.
Usman telah memasukkan asas dan prinsip Islam dalam setiap tahapnya.

Perspektif manajemen strategis syariah atau Islami telah berupaya memberikan alternatif jawaban bagi kebutuhan pengelolaan organisasi dakwah yang strategis. Harapannya, dengan model manajemen strategis syariah, maka persoalan-persoalan penyimpangan moral dalam praktik keorganisasian akan dapat dikendalikan. Karena organisasi dan seluruh anggotanya diarahkan untuk memiliki tujuan atau motif yang berdimensi spiritual, bukan hanya orientasi yang material. Sehingga sejak awal dalam proses perumusan visi, misi, dan tujuan, asas dan nilai-nilai Islam telah dimasukkan sebagai pijakan, sehingga pada tahap perumusan strategi, implementasi strategi, hingga pengendalian tidak akan bertentangan dengan syariat. Akan tetapi, terobosan yang dilakukan dalam perspektif manajemen strategis syariah terkesan masih mengikuti arus sentimen apologetis, sebagaimana yang dilakukan oleh sebagian besar gerakan islamisasi ilmu pengetahuan sejak Ismail Raji Al-Faruqi. Proses islamisasi pengetahuan yang diadopsi lebih banyak pada agenda pembenahan orientasi nilai-nilai normatifnya saja, tidak menyentuh pada aspek metodologisnya. Kerangka berpikir dalam pemecahan masalahnya masih tetap berpedoman pada kerangka berpikir konvensional. Kelebihannya hanya pada menambahkan asumsi nilai-nilai pada kerangka berpikir tersebut, tanpa mendekonstruksinya secara fundamental.

Jika diibaratkan, kerangka berpikir dan metodologi manajemen strategis 
konvensional itu sebagai produk teknologi, misalnya seperti komputer, telepon seluler, atau mesin kendaraan bermotor. Maka gagasan konsep manajemen strategis syariah sebenarnya tidak menciptakan teknologi baru, komputer baru, telepon seluler baru, atau mesin kendaraan yang baru, yang lebih inovatif atau yang lebih berdaya guna. Karena faktanya tidak ada teknologi alternatif baru yang diciptakan untuk menggantikan teknologi yang lama. Konsep manajemen strategis syariah hanya memberikan kerangka nilai-nilai etis yang harus diperhatikan oleh individu pengguna teknologi tersebut. Upaya perubahan normatifnya lebih banyak bekerja pada level kaidah penggunaan atau pemanfaatannya, bukan pada rekayasa teknologinya. Sehingga makna dari manajemen strategis syariah bukan semakna dengan komputer syariat, telepon seluler syariat, atau mesin kendaraan syariat. Karena memang tidak ada rekayasa teknologi yang menghasilkan inovasi fungsi baru berdasarkan syariat. Konsep manajemen strategis syariah ini hanya memberikan rambu-rambu etis bagi para penggunanya agar dalam pemanfaatannya diarahkan pada motif dan tujuan yang benar. Gagasan manajemen strategi syariat lebih banyak melakukan pembenahan pada sisi mental dan spiritual dari individu penggunanya, daripada pembenahan pada kerangka metodologis teori manajemen strategis konvensional itu sendiri.

Ahmad Abdul 'Adhim Muhammad juga menawarkan sebuah kerangka penerapan perencanaan strategis dengan memasukkan intervensi dari Tuhan (Allah) sebagaimana yang telah terjadi pada peristiwa hijrah. Tuhan terlibat pada proses penetapan tujuan awal serta mengawal seluruh bagian dari proses melalui petunjuk-petunjuk secara langsung kepada Rasulullah. Sehingga, proses perencanaan strategis hingga implementasinya oleh Rasulullah selalu mendapatkan intervensi strategis dan selalu berada dalam jalur pengawasan dari Allah. Tentu saja bias dipahami bahwa kerangka perencanaan strategis tersebut hanya bisa diterapkan pada konteks kenabian yang memiliki fasilitas input informasi dari langit secara langsung. Berbeda dengan proses-proses perencanaan strategis yang dilakukan oleh umat Islam pada umumnya, yang harus berhadapan secara mandiri dengan realitas lingkungan, dan secara mandiri pula harus menemukan solusinya. Prinsip-prinsip ajaran Islam yang diwahyukan oleh Tuhan melalui Alquran tentu saja bisa menjadi petunjuk, tetapi sifatnya masih etisnormatif. Tidak bersifat operasional atau teknis strategis sebagaimana yang dialami oleh Rasulullah saat itu. Sehingga, secara realistis, para pelaku dakwah harus tetap merumuskan sendiri kerangka kerja strategisnya berdasarkan tuntutan perkembangan lingkungan yang dihadapi. Prinsip-prinsip etis normatif tetap bisa menjadi input bagi kerangka strategis tersebut, akan tetapi mekanisme kerja metodologisnya harus tetap membumi. Yakni berbasis pada kebutuhan nyata dalam upaya pemecahan masalah yang ilmiah, praktis, dan tepat guna.

Jika memang demikian, maka kerangka kerja manajemen strategis konvensional sebenarnya masih tetap dianggap relevan untuk diadopsi. Tanpa harus memberikan embel-embel atau simbol Islam dan syariat sekalipun, kerangka metodologi manajemen strategis masih bisa diterapkan pada organisasi dalam bentuk apapun. Persoalan 
pembangunan mental spiritual pada personal dengan berbasis pada nilai-nilai syariat adalah persoalan yang berbeda, setidaknya bukan wilayah teknis metodologis dalam kerangka kerja manajemen strategis. Bahkan dengan kerangka manajemen strategis konvensional yang telah berkembang saat ini, masalah perumusan visi-misi dan tujuan organisasi masih bersifat terbuka oleh berbagai nilai-nilai yang berbeda. Artinya, kerangka kerja tersebut memberikan ruang yang sangat luas bagi infiltrasi paradigma dan nilai-nilai apapun, tanpa harus membongkar secara fundamental pada kerangka metodologisnya. la akan senantiasa kompatibel untuk diadaptasikan pada berbagai motif dan tujuan dari para pengguna, tanpa harus merubah identitas atau karakternya. Perspektif syariat yang tertuang pada nilai-nilai tauhid, keimanan dan ketakwaan pada Allah, kejujuran, keadilan, keseimbangan, hingga orientasi keselamatan dunia dan akhirat, dapat dengan mudah diinfiltrasikan pada teori manajemen strategis konvensional, tanpa harus menciptakan simbol manajemen strategis syariah.

\section{Paradigma Metodologis bagi Dakwah Strategis}

Perspektif syariat Islam juga harus mampu membangun terobosan-terobosan baru yang lebih fundamental. Tidak hanya kreatif dalam sekadar mengombinasikan nilai-nilai etis Islam pada kerangka kerja manajemen strategis, tapi juga menghasilkan kerangka kerja yang lebih tepat guna dan lebih efektif dalam menjawab kebutuhan organisasi dakwah, terlepas dari semangat sentimen islamisasi yang sekadar bersifat simbolik dan tidak esensial. Karena apa yang lebih esensial dibutuhkan oleh organisasi dakwah Islam adalah infrastruktur yang mampu menjawab masalahnya dalam mencapai tujuan dakwahnya secara efektif. Bukan pada simbolisasi teknologi atau ilmu pengetahuan yang dibangun dari pola pikir deduktif normatif, melainkan solusi yang dibangun dari pola pikir induktif yang berbasis pada masalah nyata. Karena pada dasarnya, nilai-nilai Islam atau syariat yang paling fundamental bisa dirujuk pada konsep kemaslahatan, maka perjuangan mencapai kemaslahatan adalah esensi dari syariat itu sendiri. Secara lebih teknis, prinsip syariat tentang kemaslahatan ini tercermin dari praktik dakwah yang mampu memberikan solusi bagi masalah masyarakat secara luas, dengan menerapkan pengelolaan organisasi yang efektif dan efisien.

Dengan melakukan analisis sintesis antara prinsip-prinsip teori manajemen strategi, khususnya kerangka kerja manajemen strategi konvensional dengan karakter serta fungsi organisasi dakwah, maka dapatlah dirumuskan beberapa ancangan metodologis bagi dakwah strategis. Pertama, prosedur penyusunan visi dan misi bagi organisasi dakwah tidak hanya melalui tahapan yang bersifat induktif, melainkan juga harus melibatkan proses deduktif yang bersumber dari tujuan penciptaan manusia dan alam semesta oleh Allah. Karena prinsip tentang tujuan penciptaan manusia dan alam semesta ini menjadi landasan yang paling fundamental bagi segala aktivitas dan tujuan perilaku manusia di dunia. Tidak boleh ada aktivitas apapun, dalam bentuk yang paling sederhana sekalipun, yang bertentangan dengan prinsip tersebut, termasuk dalam hal berorganisasi dan berdakwah. Tapi prinsip ini juga harus 
berdialog secara timbal balik dengan konteks kemanusiaan, sosial kemasyarakatan, yang menjadi latar belakang berdirinya organisasi dakwah. Sehingga prosedur penyusunan visi dan misi organisasi, harus bersumber dari landasan ideal dan aktual secara simultan, terbentuk dari logika deduktif dan induktif sekaligus. Hal ini untuk menjawab keterbatasan dari konsep manajemen strategis konvensional yang lebih mengutamakan aspek aktual induktif dan konsep manajemen strategis syariah yang lebih mengutamakan aspek ideal deduktif saja.

Kedua, metode perumusan strategi harus menghasilkan seperangkat strategi dakwah yang mempertimbangkan semua faktor strategis internal dan eksternal secara komprehensif dan sinergis, bukan strategi yang parsial dan berpotensi saling bertentangan. Metode perumusan strategi yang selama ini digunakan dalam kerangka manajemen strategi konvensional dan kemudian diadaptasi oleh manajemen strategi syariat, ternyata cenderung menggunakan analisis yang parsial. Dalam proses matching (kombinasi) faktor-faktor strategis untuk merumuskan strategi, pada umumnya manajemen strategi konvensional menggunakan matrik SWOT (Strength, Weakness, Opportunity, Threat). Prosedur matching menggunakan matrik SWOT dilakukan dengan mengombinasikan satu atau beberapa faktor strategis internal dengan satu atau beberapa faktor strategis eksternal, sehingga melahirkan empat kuadran kombinasi strategi, yaitu S-O, S-T, W-O, dan W-T. Semakin banyak jumlah faktor strategis yang dilibatkan dalam analisis SWOT, maka akan memungkinkan semakin banyak kombinasi strategi yang dihasilkan. Masing-masing strategi tersebar secara acak dalam empat kuadran, lahir dari logika sintesis (kombinasi) yang berbedabeda, terkadang tidak saling terkait satu sama lain, bahkan memungkinkan juga saling bertentangan. Himpunan berbagai strategi yang bersifat parsial dan tidak sinergis ini akan sulit sekali diimplementasikan, baik dalam organisasi komersial maupun organisasi dakwah. Tapi kerangka manajemen strategi konvensional tidak memberikan solusi teknis untuk mengatasi hal tersebut. Karena itu, organisasi dakwah perlu mengembangkan sebuah metode untuk mengklasifikasikan berbagai strategi yang parsial dalam beberapa strategi induk, mengeliminasi strategi yang saling bertentangan, serta membangun logika hubungan fungsional antar strategi. Sehingga setiap strategi yang dihasilkan dapat saling bersinergi, masingmasing memiliki kedudukan yang jelas dalam mencapai visi-misi dan tujuan organisasi.

Ketiga, posisi strategis organisasi berdasarkan hasil pemetaan lingkungan harus teridentifikasi secara akurat berdasarkan pada karakter dan indikator performance yang relevan dengan lingkungan dakwah. Dalam menetapkan posisi strategis sebuah organisasi, kerangka manajemen strategi konvensional menggunakan beberapa matrik, yaitu BCG (Boston Consulting Group), SPACE (Strategic Position dan Action Evaluation), I-E (Internal-External), dan Grand Strategy. ${ }^{28}$ Model matrik BCG dan SPACE dibentuk berdasarkan beberapa variabel yang lebih relevan dengan konteks organisasi

\footnotetext{
${ }^{28}$ David, Manajemen Strategis., 323-349.
} 
komersial, yaitu variabel tingkat pertumbuhan industri, posisi pangsa pasar, keunggulan kompetitif, kekuatan finansial, dan stabilitas lingkungan industri. Sedangkan model matrik I-E dan grand strategy, ditentukan oleh skor performance faktor internal dan faktor eksternal. Akan tetapi, semua model matrik tersebut menawarkan paket-paket strategi pada setiap kuadran berbasis pada konteks industrial, yaitu strategi untuk memenangkan atau mengantisipasi kompetisi di pasar. Tentu saja, posisi strategis dan paket-paket strategi tersebut tidak relevan dengan konteks organisasi dakwah. Sehingga perlu dikembangkan berbagai kriteria performance baru yang lebih relevan dengan karakter organisasi dakwah, atau dengan cara melakukan pemaknaan ulang terhadap kriteria performance industrial tersebut agar mengakomodasi konteks lingkungan dakwah.

Keempat, metode pemilihan strategi harus juga mempertimbangkan aspek efektivitas, efisiensi, dan kontinuitas proses dakwah. Dalam kerangka manajemen strategi konvensional, metode pemilihan strategi yang direkomendasikan adalah menggunakan matrik QSPM (Quantitative Strategic Planning Matrix) ${ }^{29}$, setiap strategi diuji tingkat relevansinya secara relatif dengan seluruh faktor-faktor strategis. Sebuah alternatif strategi akan memiliki peringkat yang tinggi secara relatif terhadap strategi-strategi lain, jika ia memiliki relevansi dengan lebih banyak faktor strategis. Sebaliknya, semakin sedikit jumlah faktor strategis yang relevan, maka peringkat relatif sebuah alternatif strategi akan semakin buruk, dan sebaiknya tidak diimplementasikan. Metode ini, secara tidak langsung telah mengabaikan aspek efektivitas, efisiensi, dan kontinuitas sebuah strategi dalam dakwah. Padahal, bagi organisasi dakwah, sangat penting untuk mempertimbangkan sejauh mana strategi dakwah mampu mencapai tujuannya spesifiknya, sesuai dengan kapasitas internalnya, serta mampu menjamin keberlangsungan dakwah pada masyarakat. Karena itu, perlu dikembangkan berbagai kriteria pemilihan strategi yang lebih komprehensif dan relevan dengan lingkungan dakwah.

Kelima, paradigma metodologis tersebut sangat penting bagi organisasi dakwah agar dapat mengadopsi kerangka kerja manajemen strategi atau mengembangkan dakwah strategis. Paradigma tersebut juga harus dirancang secara lebih teknis, dengan melibatkan variabel-variabel yang lebih spesifik dihadapi oleh setiap organisasi dakwah. Bisa jadi, berbagai pendekatan dakwah dan model organisasi dakwah yang berbeda, akan membutuhkan kerangka kerja teknis yang berbeda pula. Setidaknya, ancangan paradigma metodologis tersebut dapat menjadi pijakan awal dan sumber inspirasi bagi upaya pengembangan metode dakwah strategis yang lebih mengakomodasi kebutuhan organisasi dakwah modern.

Dalam upaya mengembangkan kerangka kerja dakwah strategis serta mengimplementasikannya pada organisasi dakwah modern, tentu saja tidaklah mudah. Terdapat berbagai tantangan yang harus dihadapi, terkait konteks perkembangan

29 Ibid., 349-357. 
organisasi dakwah di Indonesia dan juga di negara-negara Islam lainnya. Setidaknya terdapat beberapa tantangan struktural dalam menerapkan manajemen strategis sebagai kerangka kerja manajemen organisasi dakwah di Indonesia. ${ }^{30}$

Pertama, pola pikir masyarakat Indonesia yang masih menganggap bahwa dakwah adalah bagian tugas sebagian umat Islam yang berdimensi ibadah ritual yang penuh dengan nilai-nilai sakralitas, rohaniah, dan ukhrawi. Sehingga dakwah tidak bisa diukur dengan indikator-indikator profesionalitas yang material dan duniawi, apalagi yang berdimensi komersial. Dakwah dianggap memiliki dunia sendiri yang sangat pribadi, terkait dengan urusan privat dalam hubungannya dengan Tuhan, yang harus memiliki imunitas dari pengaruh segala yang bersifat profan, ilmiah, sekuler, apalagi yang sumbernya tidak berasal dari teks-teks suci. Hal ini yang membuat kehidupan umat Islam menjadi sangat ahistoris, berjarak dengan realitas nyata yang dihadapi dalam kesehariannya. Islam dan umat Islam tidak mampu menjadi bagian dari solusi atas masalah nyata masyarakat, bahkan tidak jarang pula dianggap sebagai bagian dari sumber masalah. Sangat memprihatinkan jika upaya dakwah yang tujuannya sangat positif, tanpa disadari justru bersifat kontraproduktif bagi pembangunan masyarakat dan umat Islam. Karena itu, perlu ada upaya yang masif dan sinergis oleh semua elemen umat Islam, untuk memberikan edukasi tentang makna dakwah secara esensial, sebagaimana yang telah dicontohkan oleh Rasulullah dan Walisongo. Agar umat Islam Indonesia berhasil menangkap spirit kontekstual dari contoh tersebut, bukan sekadar menangkap kaidah praktik tekstual yang dapat menjauhkannya hakikat dari misi dakwah.

Kedua, tidak bisa dipungkiri, bahwa umat Islam di Negara-negara berkembang masih sangat tertinggal dari aspek pembangunan kualitas manusia. Secara umum akses pada pendidikan yang berkualitas serta tingkat pengenalan literasinya masih sangat rendah, meskipun ada juga perkecualian untuk sejumlah kecil individu muslim yang telah berpendidikan tinggi dan berwawasan luas. Kelemahan kualitas sumber daya manusia muslim ini tercermin pada kapasitas kelembagaan umat Islam yang masih belum berdaya menghadapi kemajuan kompetisi dengan lembagalembaga komersial. Masih banyak organisasi dakwah yang berbasis masjid atau sekolah Islam yang dikelola dengan berbekal semangat pengabdian suka rela dengan menerapkan manajemen keikhlasan, yang masih jauh dari nilai-nilai produktivitas, kreativitas, dan profesionalitas. Kondisi ini tentu saja akan menghambat kemampuan umat Islam dalam mengadaptasi serta mengembangkan ilmu pengetahuan dan inovasi teknologi dalam rangka menjalankan misi pembangunan masyarakat yang rahmatan lil alamin. Kelemahan ini akan membuat kapasitas sumber daya umat Islam tidak terkelola secara optimal, kapasitasnya dalam melakukan perubahan menuju perbaikan masyarakat menjadi sangat rendah dan tidak berdaya. Rendahnya kualitas sumber daya manusia akan melemahkan organisasi dakwah dalam menerapkan teknologi, dalam belajar dari pengalaman, dalam mengembangkan inovasi dan strategi baru, dan dalam semua

\footnotetext{
${ }^{30}$ Affandy, Dakwah Strategis., 182-186.
} 
kemampuan untuk memecahkan masalah. Padahal, penerapan kerangka kerja manajemen strategis sangat membutuhkan kemampuan dalam analisis lingkungan, melakukan assessment, membuat prediksi, kreativitas dalam merumuskan strategi, mengimplementasikan strategi, hingga mengevaluasi secara akurat seluruh prosesnya. Oleh karena itu, perlu banyak dilakukan upaya pengembangan kapasitas SDM dakwah untuk mengenal, memahami, dan mempraktikkan berbagai pendekatan dalam pengelolaan organisasi secara profesional.

Ketiga, satu tantangan struktural yang paling krusial, selain masalah mindset dan kualitas SDM, adalah pentingnya perkembangan teori-teori manajemen yang lahir secara induksi dari persoalanpersoalan nyata umat Islam. Saat ini, tidak bisa dipungkiri, bahwa perkembangan riset di bidang filsafat, ilmu pengetahuan, dan teknologi masih didominasi oleh ilmuwanilmuwan dari Barat yang mengabdi pada kepentingan dunia industri. Sehingga teoriteori dan teknologi yang diciptakan cenderung berhaluan ideologi kapitalisdevelopmentalis dan berbasis pada konteks industri komersial. Belum banyak riset-riset ilmiah di bidang ilmu manajemen yang lahir secara genetik khusus untuk menjawab masalah-masalah organisasi sosial atau organisasi dakwah. Sehingga organisasi dakwah memiliki kesulitan teknis dalam mengadopsi atau mengadaptasikan kerangka manajemen organisasi komersial untuk diterapkan pada organisasi dakwah. Karena hampir semua variabel, dimensi dan indikator dalam teori manajemen konvensional mengukur capaian-capaian material. Sementara bagi organisasi dakwah, cara kerja dan ukuran kinerjanya sebagian besar bersifat abstrak, psikologis, dan rohaniah. Karena itu, perlu dikembangkan inovasi-inovasi teoritis dalam kerangka metodologis dalam ilmu manajemen dakwah, bukan hanya sekadar menambahkan paradigma etis atau simbolsimbol keislaman. Para sarjana dan ilmuwan Islam harus berinisiatif dalam mengembangkan riset-riset ilmiah dengan pendekatan kualitatif induktif untuk melahirkan konsep dan teor-teori manajemen baru yang kompatibel untuk kebutuhan organisasi dakwah ke depan.

\section{Kesimpulan}

Tidak dapat dipungkiri, bahwa organisasi dakwah modern membutuhkan sebuah kerangka kerja manajemen yang tepat untuk menghadapi dinamika lingkungan dakwah. Manajemen strategi adalah sebuah disiplin yang sangat relevan dengan kebutuhan pengelolaan organisasi dakwah yang visioner, yang senantiasa belajar untuk beradaptasi dengan lingkungan, serta bekerja dalam irama yang sinergis dan berkesinambungan. Akan tetapi, konsep manajemen strategi konvensional lahir, berkembang, dan berorientasi pada konteks organisasi komersial yang sangat berbeda dengan lingkungan organisasi dakwah. Karena itu, dibutuhkan suatu upaya untuk mengadopsi kerangka kerja manajemen strategi konvensional secara fundamental agar mampu menjawab kebutuhan organisasi dakwah modern. Upaya itu harus meliputi pengembangan paradigma baru pada aspek etis dan aspek metodologis secara simultan, agar kerangka kerja manajemen strategi mampu lebih berdaya guna dan compatible bagi terwujudnya program dakwah yang efektif dan 
berkesinambungan. Karena dakwah bukan hanya proses menyampaikan kebenaran saja, melainkan juga proses dialogis dengan lingkungan hingga menghasilkan perubahan sosial yang efektif. Sehingga, proses dan paradigma dakwah harus bisa bertransformasi menjadi dakwah strategis.

Manajemen strategis syariah telah menawarkan seperangkat paradigma etis bagi dakwah strategis yang meliputi penambahan asas syariat, motivasi humanistik, dan tujuan keakhiratan dalam visi-misi. Kemudian ditekankan juga tentang penerapan nilai etis dan hukum muamalah Islam pada proses formulasi strategi dan implementasinya. Dilanjutkan dengan proses pengendalian dan evaluasi yang menekankan kriteria kinerja yang berbasis pada nilai Ihsan dan ketakwaan. Untuk mengaplikasikan seperangkat paradigma etis tersebut, maka perlu juga dilakukan berbagai perombakan pada aspek paradigma metodologisnya. Upaya perombakan metodologis ini meliputi pembenahan prosedur dalam kerangka analisis manajemen strategi, mulai tahap perumusan visi-misi, analisis lingkungan (SWOT), perumusan dan pemilihan strategi. Tanpa melakukan perombakan pada sisi metodologis tersebut, maka paradigma etis syariat tidak akan bisa termanifestasikan secara operasional dalam kerangka kerja dakwah strategis.

\section{Bibliografi}

Affandy, Shofyan. Dakwah Strategis: Sebuah Ancangan Teoritis dan Filosofis. Surabaya: Avvaterra, 2017.

Allison, Michael dan Kaye, Jude. Perencanaan Strategis Bagi Organisasi Nirlaba. Jakarta: Yayasan Obor Indonesia, 2004.

Anshoff, H. Igor dan McDonnell, Edward J. Implementing Strategic Management, 2nd edition. New York: Prantice Hall, 1990.

David, Fred. Manajemen Strategis: Konsep. Jakarta: Salemba Empat, 2010.

Hunger, David dan Wheelen, Thomas L. Manajemen Strategis. Yogyakarta: Penerbit Andi, 2009. Lubis, S.B. Hari. Pengantar Manajemen Strategi. Bandung: TP, 1992.

Muchtarom, Zaini. Dasar-dasar Manajemen Dakwah. Yogyakarta : Penerbit Al-Amin dan Ikfa. Muhammad, Ahmad Abdul 'Adhim. Strategi Hijrah: Prinsip-Prinsip Ilmiah dan Ilham Tuhan, Solo: Tiga Serangkai, 2004.

Pearce, John A. dan Robinson, Richard B. Manajemen Strategis: Formulasi, Implementasi, dan Pengendalian, Jilid 1. Tangerang: Bina Rupa Aksara.

Usman, Abdul Halim. Manajemen strategis syariah: Teori, Konsep, dan Aplikasi. Jakarta: Zikrul Hakim, 2015.

Yusanto, M.I. dan Widjajakusuma, M.K. Menggagas Bisnis Islami, Jakarta: Gema Insani, 2002. . Manajemen Strategis Perspektif Syariat, Jakarta: Khairul Bayaan, 2003. 